\title{
OPTIMASI FORMULA MIKROEMULSI BERBAHAN DASAR CRUDE PALM OIL (CPO) SEBAGAI ANTIOKSIDAN POTENSIAL PADA KULIT
}

\author{
The Optimization of CPO-Based Microemulsion as an Antioxidant for Skin
}

\author{
Erga Syafitri ${ }^{{ }^{\star}}$, Nur Adliani ${ }^{1}$, Sudewi Mukarromah Khoirunnisa ${ }^{1}$, dan Fina Khaerunnisa \\ Frima $^{2}$ \\ ${ }^{1}$ Program Studi Farmasi, Institut Teknologi Sumatera \\ ${ }^{2}$ Program Studi Kimia, Institut Teknologi Sumatera \\ Jl. Terusan Ryacudu, Way Huwi, Kec. Jati Agung, Kabupaten Lampung Selatan, Lampung \\ ${ }^{*}$-mail: erga.syafitri@fa.itera.ac.id
}

\begin{abstract}
Crude Palm Oil (CPO) is one of the typical Indonesian plant that has potential effect as an antioxidant preparation. The purpose of this study was to produce microemulsion with CPO content that had good physical characteristics and also showed antioxidant activity. This research was divided into 3 stages i.e. microemulsion formulation, physical characterization and stability, and antioxidant activity evaluation. The microemulsion was formulated using Phase Titration Method with CPO as oil phase, surfactant tween 80, cosurfactant PEG 400 and aquadest. The treatment in this study was the addition of CPO with various concentration of $5 \%, 7.5 \%$, and $10 \%(\mathrm{w} / \mathrm{w})$. The optimum formula was $A 1$ which contained $5 \%(\mathrm{w} / \mathrm{w}) \mathrm{CPO}$. The results showed that this formula had a globule size of $288.87 \pm 20.94 \mathrm{~nm}$, zeta potential of $-0.36 \mathrm{mV}$, density of $1.024 \pm 6.15 \times 10-5 \mathrm{~g} / \mathrm{mL}$, and $\mathrm{pH}$ in the range of 4.5-6.5. The microemulsion was stable in storage for 28 days at $25^{\circ} \mathrm{C}$, stable against extreme temperature changes and agitation. The CPO-based microemulsion had IC50 value of $10.5 \mu \mathrm{g} / \mathrm{mL}$ which showed strong antioxidant activity. It can be concluded that CPO-based microemulsion had good physical stability and antioxidant activity for further cosmetic preparation.
\end{abstract}

Keywords: antioxidant, skin, microemulsion, crude palm oil (CPO), PEG 400.

Abstrak: Minyak Kelapa Sawit Mentah (Crude Palm Oil/CPO) merupakan salah satu tanaman khas Indonesia yang berpotensi sebagai sediaan antioksidan. Tujuan dari penelitian ini adalah untuk menghasilkan sediaan mikroemulsi mengandung CPO yang memiliki karakteristik fisik yang baik serta menunjukkan aktivitas antioksidan. Penelitian ini terbagi menjadi 3 tahap, yaitu formulasi mikroemulsi CPO, karakterisasi fisik dan stabilitas, dan evaluasi aktivitas antioksidan. Mikroemulsi CPO diformulasikan menggunakan metode Phase Titration Method dengan CPO sebagai fase minyak, tween 80 sebagai surfaktan, PEG 400 sebagai kosurfaktan dan aquadest sebagai fase air. Perlakuan pada penelitian ini yaitu penambahan CPO dengan variasi konsentrasi sebesar 5\%, 7,5\%, dan $10 \%(\mathrm{~b} / \mathrm{b})$. Formula optimum dari penelitian ini adalah formula A1 yang mengandung 5\% (b/b) CPO. Hasil evaluasi formula menunjukkan bahwa formula ini memiliki ukuran globul sebesar $288,87 \pm$ $20,94 \mathrm{~nm}$, zeta potensial sebesar $-0,36 \mathrm{mV}$, bobot jenis $1,024 \pm 6,15 \times 10^{-5} \mathrm{~g} / \mathrm{mL}$ dan $\mathrm{pH}$ berada pada rentang 4,5-6,5. Formula tersebut stabil dalam penyimpanan selama 28 hari pada suhu ruang $\left(25^{\circ} \mathrm{C}\right)$, stabil terhadap perubahan suhu ekstrim dan agitasi. Sediaan mikroemulsi CPO memiliki nilai IC50 sebesar $10,5 \mu \mathrm{g} / \mathrm{mL}$ yang menunjukkan aktivitas antioksidan yang kuat. Selain itu, mikromeulsi ini memiliki karakterisasi fisik dan kestabilan yang baik sehingga dapat dikembangkan lebih lanjut sebagai sediaan antioksidan pada kulit.

Kata kunci: antioksidan, kulit, mikroemulsi, minyak kelapa sawit (CPO), PEG 400.

\section{PENDAHULUAN}

Perkebunan kelapa sawit telah berhasil membawa Indonesia menjadi produsen sawit terbesar dunia. Hal tersebut membuat hasil pengolahan kelapa sawit menjadi sumber daya alam yang potensial untuk dimanfaatkan, mulai dari buah, minyak, sampai ke cangkang buahnya (Nasution dan Limbong, 2019). Salah satu turunan kelapa sawit yang banyak dimanfaatkan adalah Minyak Kelapa Sawit Mentah 
(Crude Palm Oil/CPO). Kontribusi ekspor minyak sawit dan turunannya meningkat hingga 2,78 juta ton pada Maret 2019 dan menghasilkan devisa negara yang sangat signifikan bagi perekonomian Indonesia (Anonim, 2019). Pemanfaatan minyak kelapa sawit dalam dunia kesehatan terutama obat-obatan dan kosmetik masih sangat terbatas padahal jenis minyak ini berpotensi dijadikan sebagai antioksidan yang bermanfaat untuk kulit.

CPO diperoleh dari lapisan serabut/kulit buah sawit melalui proses pengolahan minyak sawit (Anonim, 2007). Pada suhu kamar, CPO adalah minyak yang setengah padat. Warna merah jingga dikarenakan adanya kandungan karoten (provitamin A) dan vitamin $E$ dalam jumlah yang banyak $(0,05-0,20 \%)$. Karotenoid ini berfungsi sebagai antioksidan untuk tubuh dan dapat menangkal radikal bebas sehingga mencegah pembentukan kerut pada kulit (Anonim, 2007; $\mathrm{Ng}$ et al., 2013; Yuliasari et al., 2014). CPO juga bersifat nontoksik dan mudah diperoleh. Oleh karena itu, CPO dapat digunakan secara potensial sebagai sediaan kosmetik antioksidan pada kulit. Namun, CPO sebagian besar terdiri dari trigliserida yang bersifat minyak dan kurang nyaman untuk digunakan dalam sediaan kosmetik (Flanagan dan Singh, 2006) sehingga CPO perlu diformulasikan dalam bentuk emulsi atau mikroemulsi untuk meningkatkan keberterimaan pengguna.

Mikroemulsi merupakan suatu sistem dispersi yang dikembangkan dari sediaan emulsi. Sistem ini stabil secara termodinamika, jernih, dan transparan (Talegaonkar et al., 2008; Dijaz, 2013). Mikroemulsi memiliki beberapa kelebihan dibandingkan sediaan emulsi konvensional, yaitu stabil dalam jangka waktu lama secara termodinamika, mempunyai daya larut yang tinggi serta mempunyai kemampuan penetrasi yang baik (Flanagan and Singh, 2006; Kale dan Deore, 2017). Selain itu, mikroemulsi memiliki peran penting dalam menjaga kestabilan obat dan mengontrol pelepasan obat (Subramanian, 2005; Narang et al.,
2007). Mikroemulsi dibentuk dengan energi yang rendah dan spontan untuk menghasilkan campuran yang stabil secara termodinamika. Oleh karena itu, dibutuhkan konsentrasi surfaktan yang tinggi $(20 \% \mathrm{w} / \mathrm{w})$ untuk menghasilkan mikroemulsi sesuai persyaratan yang diinginkan (Asri et al., 2017). Komponen dari mikroemulsi terdiri dari fase terdispersi (fase dalam), fase pendispersi (fase luar), surfaktan, dan kosurfaktan. Kosurfaktan berfungsi untuk meningkatkan fleksibilitas antarmuka dari sistem nanoemulsi sehingga pembentukan nanoemulsi spontan lebih mudah tercapai (Kale dan Deore, 2017).

Pembuatan mikroemulsi terdiri dari 2 metode, yaitu Phase Titration Method dan Phase Inversion Temperature Method (PIT). Pada metode Phase Titration Method, mikroemulsi dibuat dengan memanfaatkan pengadukan dan komposisi dari surfaktan dan kosurfaktan. Sedangkan pada metode PIT, pembentukan mikroemulsi memanfaatkan kenaikan temperatur ketika surfaktan ditambahkan ke dalam sistem sehingga membantu untuk menurunkan tegangan permukaan antara fase minyak dan fase air (Kale dan Deore, 2017).

Tween 80 merupakan surfaktan nonionik yang bersifat nontoksik dan nonirritant. Surfaktan ini umum digunakan pada formulasi mikroemulsi karena memiliki keseimbangan lipofilik dan hidrofilik yang baik serta stabil terhadap asam lemah dan basa lemah (Ramli et al., 2019; Pamudji et al., 2012). Untuk meningkatkan kemampuannya sebagai emulgator, tween 80 biasa dikombinasikan dengan surfaktan lain seperti span 80 atau kosurfaktan seperti PEG 400 dan propilen glikol. Kombinasi ini akan menghasilkan lapisan film yang rapat antara minyak dan air (Kale dan Deore, 2017; Patel et al., 2010).

PEG 400 adalah senyawa glikol rantai pendek dengan pemerian tidak berwarna, kental, dan tidak berbau (Ramli et al., 2019). PEG 400 dapat digunakan sebagai kosurfaktan karena memiliki gugus rantai karbon yang 
pendek sehingga dapat mengisi ruang antarsurfaktan dan menurunkan tegangan antarmuka (Asri et al., 2017). Kombinasi surfaktan tween 80 dan kosurfaktan PEG 400 dalam mikroemulsi telah dilakukan dalam penelitian sebelumnya menggunakan berbagai macam minyak, seperti minyak asam oleat (Asri et al., 2017), minyak zaitun (Jha et al., 2011) capmul MCM (Patel et al., 2010), minyak sereh (Hasrawati et al., 2016), dan limonene (Ramli et al., 2019). Namun, untuk formulasi mikroemulsi dengan fase minyak kelapa sawit mentah belum pernah dipublikasikan sebelumnya.

Penelitian ini bertujuan untuk mendapatkan formula optimum sediaan mikroemulsi mengandung CPO dengan berbagai variasi konsentrasi minyak. Formula optimum dari mikroemulsi ini akan diuji aktivitas antioksidannya sehingga dapat diketahui potensinya sebagai sediaan antioksidan alami untuk wajah.

\section{METODOLOGI}

\section{Bahan dan Alat}

Bahan baku yang digunakan pada penelitian ini adalah minyak Kelapa Sawit (Crude Palm Oil/CPO) yang diperoleh dari PPKS Sumatera Utara, Tween 80 (Bratachem), Polietilen Glikol (PEG) 400 (Bratachema), DPPH (2,2difenil-1-pikrilhidrazil) dan aquadest (Bratachem). Sedangkan alat yang digunakan adalah timbangan analitik (Kern/Type ADB200-4), magnetic stirrer (Velp MST Digital), alat sentrifuga (DS Lab), pH meter (Milwaukee, USA Mi150), oven (Thermo Scientific, Cat\#OGS180), kulkas, Zetasizer Nano ZS, Particle Size Analyzer (PSA), Transmission Electron Microscopy (TEM), Spektrofotometer UV-Vis (Thermo Scientific), dan alat gelas lainnya.

\section{Metode Penelitian}

Penelitian ini dilaksanakan menggunakan metode eksperimental untuk melihat pengaruh variasi konsentrasi CPO terhadap karakteristik fisik dan stabilitas fisik sediaan mikroemulsi CPO. Konsentrasi komponen lain dibuat konstan. Tahapan penelitian ini terbagi menjadi 3, yaitu tahap formulasi mikroemulsi CPO, tahap evaluasi karakteristik fisik dan stabilitas mikroemulsi, dan tahap evaluasi aktivitas antioksidan sediaan mikroemulsi.

\section{Formulasi Mikroemulsi CPO Menggunakan Variasi Konsentrasi CPO}

Metode pembuatan mikroemulsi ini diadaptasi dari penelitian Fitriani, et al. (2016) menggunakan metode Phase Titration Method. Mikroemulsi dibuat dengan mencampurkan CPO sebagai fase minyak dengan tween 80 sebagai surfaktan dan PEG 400 sebagai kosurfaktan. Dilakukan optimasi variasi konsentrasi CPO sebagai fase minyak terhadap komponen lain dalam mikroemulsi. Jumlah CPO yang dioptimasi yaitu sebesar $5 \%$ (Formula A1), 7,5\% (Formula A2), dan 10\% (Formula A3) dari total jumlah mikroemulsi. Jumlah tween 80 dan PEG 400 sama pada tiap-tiap formula yaitu sebesar $30 \%$. Perbandingan tween 80 dan PEG 400 menggunakan hasil dari penelitian sebelumnya (Syafitri, et al., 2019) dengan perbandingan tween 80:PEG 400 sebesar 2:1. Setelah itu, campuran diaduk menggunakan magnetic stirrer dengan kecepatan 750 rpm selama 30 menit. Campuran fase minyak dan surfaktan tersebut diteteskan air (ditambahkan hingga 100\%) sedikit demi sedikit sebagai fase luar dengan kecepatan $750 \mathrm{rpm}$ selama beberapa waktu. Ketiga formula dengan variasi konsentrasi CPO tersebut dibandingkan hasil evaluasi fisik dan stabilitasnya. Formula terpilih adalah formula yang menunjukkan karakteristik fisik dan stabilitas yang baik yang kemudian dievaluasi aktivitas antioksidannya.

\section{Evaluasi dan Karakterisasi Fisik Mikroemulsi CPO}

Evaluasi mikroemulsi CPO meliputi evaluasi organoleptik, bobot jenis, penentuan $\mathrm{pH}$, Pengukuran Globul dan Indeks Polidispersitas, Pengukuran Zeta Potensial, Uji Stabilitas Fisik 
Mikroemulsi, dan Morfologi Mikroemulsi.

\section{Organoleptik}

Pengamatan dilakukan terhadap sediaan mikroemulsi yang dilakukan selama 28 hari dengan mengamati adanya perubahan pada warna, bau, kejernihan, dan endapan.

\section{Bobot Jenis}

Penentuan bobot jenis sediaan dilakukan dengan menggunakan piknometer pada suhu $25^{\circ} \mathrm{C}$. Piknometer kosong ditimbang sebagai $\mathrm{W}_{0}$, kemudian piknometer yang berisi mikroemulsi dihitung sebagai $W_{1}$ dan ditimbang piknometer berisi air $\left(\mathrm{W}_{\text {air }}\right)$. Bobot jenis sediaan akan didapat dari persamaan berikut ini:

Bobot Jenis $(\mathrm{g} / \mathrm{mL})=\left(\mathrm{W}_{1}-\mathrm{W}_{0}\right) /\left(\mathrm{W}_{\text {air }}-\mathrm{W}_{0}\right)$

\section{Pengukuran Globul}

Pengukuran globul mikroemulsi menggunakan alat Particle Size Analyzer (PSA) (Silva et al., 2013). Sebelumnya sampel diencerkan terlebih dahulu dengan aquadest dengan perbandingan 1:100 (v/v) dan dilakukan 3 kali replikasi. Sampel dimasukkan ke dalam alat dan hasil pengukuran ditampilkan pada layar.

\section{Pengukuran Zeta Potensial}

Zeta Potensial sediaan mikroemulsi diukur menggunakan metode dynamic light scattering dengan alat Zetasizer Nano ZS (Silva et al., 2013). Sebelumnya sampel diencerkan terlebih dahulu dengan aquadest dengan perbandingan 1:100 (v/v) dan dilakukan 3 kali replikasi. Sampel dimasukkan ke dalam alat dan hasil pengukuran ditampilkan pada layar.

\section{Penentuan pH}

Elektroda dicelupkan ke dalam air sebelumnya untuk dibilas dan kemudian dimasukkan ke dalam mikroemulsi sampai terlihat angka yang muncul pada instrumen. Jika angka tersebut konstan dan tidak bergerak, maka angka tersebut dinyatakan sebagai $\mathrm{pH}$ mikroemulsi.

\section{Uji Stabilitas Fisik Mikroemulsi}

Formula mikroemulsi CPO diuji dengan 3 studi stabilitas (Pamudji et al., 2012), yaitu :

a. Uji Stabilitas Fisik pada suhu $25^{\circ} \mathrm{C}$ : Uji stabilitas dilakukan selama 28 hari dan diamati adanya ketidakstabilan seperti creaming dan cracking.

b. Uji Sentrifugasi : mikroemulsi disentrifugasi selama 30 menit dengan kecepatan $3500 \mathrm{rpm}$ dan dan diamati adanya ketidakstabilan seperti creaming dan cracking.

c. Siklus Freeze Thaw : mikroemulsi ditempatkan pada suhu $-21^{\circ} \mathrm{C}$ dan 25ㄷ dengan waktu penyimpanan pada setiap suhu selama 48 jam. Kemudian diamati adanya ketidakstabilan seperti creaming dan cracking.

\section{Morfologi Mikroemulsi}

Morfologi mikroemulsi diamati dengan Transmission Electron Microscopy (TEM) dengan perbesaran 15000x.

\section{Uji Aktivitas Antioksidan Mikroemulsi CPO}

Pengujian aktivitas antioksidan sediaan mikroemulsi CPO ini diadaptasi dari penelitian Syafitri et al. (2019). Formula mikroemulsi terbaik dilarutkan ke dalam metanol kemudian dibuat dalam beberapa konsentrasi yaitu 0,15 $\mu \mathrm{g} / \mathrm{mL}, 15 \mu \mathrm{g} / \mathrm{mL}, 30 \mu \mathrm{g} / \mathrm{mL}, 45 \mu \mathrm{g} / \mathrm{mL}$, $60 \mu \mathrm{g} / \mathrm{mL}, 75 \mu \mathrm{g} / \mathrm{mL}$, dan $90 \mu \mathrm{g} / \mathrm{mL}$. DPPH sebanyak $50 \mu \mathrm{g} / \mathrm{mL}$ kemudian direaksikan ke dalam sampel dengan perbandingan 1:1. Setelah direaksikan, dilakukan inkubasi selama 30 menit di tempat gelap. Pengukuran dilakukan dengan menggunakan spektrofotometer UV-Sinar tampak pada panjang gelombang maksimal $517 \mathrm{~nm}$. Pelarut metanol digunakan sebagai blanko, larutan DPPH $50 \mu \mathrm{g} / \mathrm{mL}$ sebagai kontrol, dan asam askorbat sebagai pembanding. Aktivitas peredaman DPPH pada mikroemulsi didapatkan dari persentase penurunan absorbansi larutan DPPH pada sampel uji. Konsentrasi sampel uji yang menyebabkan penurunan $50 \%$ aktivitas DPPH didefinisikan sebagai IC50. IC50 peredaman DPPH sampel dapat dihitung 
melalui kurva kalibrasi yang menunjukkan hubungan antara konsentrasi dan absorbansi sampel uji.

\section{HASIL DAN PEMBAHASAN}

\section{Formulasi Sediaan Mikroemulsi}

Mikroemulsi pada penelitian ini dibuat dengan metode titrasi fase (Phase Titration Method). Metode ini dipilih karena lebih sederhana dan relatif lebih murah dibandingkan dengan metode Phase Inversion Temperature (PIT). Selain itu, globul yang dihasilkan cenderung lebih homogen karena pembentukan globul didasarkan pada kecepatan dalam lama pengadukan yang konstan. Surfaktan dan kosurfaktan akan membentuk lapisan film rapat di antara globul-globul minyak selama proses pengadukan. Proses pengadukan juga diperlukan untuk memecah minyak dan membentuk globul-globul dengan ukuran kecil. Oleh karena itu, diperlukan beberapa optimasi dalam metode ini, yaitu optimasi jumlah PEG 400 dan optimasi jumlah CPO.

Pada penelitian sebelumnya (AI Abood et al. 2013; Syafitri et al. 2019) telah dibuktikan bahwa kombinasi tween 80 dan PEG 400 merupakan pilihan yang tepat untuk menghasilkan sediaan mikroemulsi dengan karakteristik dan stabilitas fisik yang baik. Dari penelitian tersebut, diperoleh bahwa kombinasi tween 80:PEG 400 sebesar 2:1 menghasilkan formula yang jernih dan stabilitas yang baik selama 7 hari. Oleh karena itu, pada penelitian ini kombinasi tween 80:PEG 400 dibuat konstan sebesar 2:1. Selain itu, jumlah surfaktan dan kosurfaktan dibuat tetap sebesar $30 \%$ (b/b). Hal ini disebabkan karena konsentrasi surfaktan yang tinggi (melebihi $30 \%(b / b)$ ) dari keseluruhan formula dapat mengakibatkan iritasi pada kulit.

Optimasi jumlah CPO dilakukan untuk melihat perbedaan fisik dan stabilitas mikroemulsi yang dihasilkan dengan berbagai persentase CPO. Komposisi ketiga formula tersebut dapat terlihat pada Tabel 1. Kemudian formulaformula tersebut dievaluasi dan dibandingkan karakteristik fisik dan stabilitasnya.

Tabel 1. Formula Optimasi Jumlah CPO

\begin{tabular}{ccccccc}
\hline Formula & $\begin{array}{c}\text { Tween 80: } \\
\text { PEG 400 }(\%)\end{array}$ & $\begin{array}{c}\text { CPO } \\
(\%)\end{array}$ & $\begin{array}{c}\text { Air } \\
(\%)\end{array}$ & $\begin{array}{c}\text { Bobot Jenis } \\
(\mathrm{g} / \mathrm{mL})\end{array}$ & $\begin{array}{c}\text { Ukuran Globul } \\
\text { Rata-rata }(\mathrm{nm})\end{array}$ & $\begin{array}{c}\text { Zeta } \\
\text { Potensial } \\
(\mathrm{mV})\end{array}$ \\
\hline A1 & 30 & 5 & 65 & $1,024 \pm 6,15 \times 10^{-5}$ & $288,87 \pm 20,94$ & $-0,36$ \\
A2 & 30 & 7,5 & 62,5 & $1,029 \pm 8,05 \times 10^{-5}$ & $574,2 \pm 25,04$ & $-0,87$ \\
A3 & 30 & 10 & 60 & $1,026 \pm 6,15 \times 10^{-5}$ & $832,07 \pm 27,84$ & 2,91 \\
\hline
\end{tabular}

\section{Organoleptik}

Evaluasi pertama adalah evaluasi
organoleptik, dimana evaluasi ini
dilakukan dengan menyimpan
mikroemulsi pada suhu ruang (25ㅇ) selama 28 hari. Sediaan mikroemulsi yang diharapkan adalah yang memiliki penampakan jernih, warna kuning dan tidak terbentuk adanya endapan. Hasil evaluasi organoleptik dapat dilihat pada Tabel 2 dan Gambar 1. Dari hasil evaluasi, terlihat bahwa formula A1 menunjukkan evaluasi fisik yang paling baik sampai hari ke-21. Sedangkan formula A2 dan A3 mengalami kekeruhan pada hari ke-21 dan ke-14. Hal ini dapat disebabkan karena tingginya konsentrasi minyak sehingga memungkinkan terjadinya inversi fasa atau keluarnya fase minyak dari fase dalam dan menyebabkan kekeruhan. Bentuk morfologi formula A1 dapat dilihat pada Gambar 2. Dari gambar tersebut, terlihat bahwa globul sediaan mikroemulsi A1 berbentuk sferis dan seragam antarglobul satu dengan globul yang lainnya. Selain itu, jarak antar globul terpisah dengan baik. Hal ini sejalan dengan hasil zeta potensial dimana zeta potensial formula mikroemulsi A1 sebesar $-0,36 \mathrm{mV}$. Zeta potensial ini menunjukkan muatan permukaan antarglobul mikroemulsi yang 
menghasilkan jarak antarglobul, sehingga

globul tidak saling menyatu atau

membentuk flok.

Tabel 2. Hasil Organoleptik Formula Optimasi Jumlah CPO

\begin{tabular}{cccccc}
\hline \multirow{2}{*}{ Formula } & & \multicolumn{3}{c}{ Pengamatan Hari ke- } \\
& 0 & 7 & 14 & 21 & 28 \\
\hline \multirow{4}{*}{ A1 } & Jernih & Jernih & Jernih & Jernih & Agak keruh \\
& Warna & Warna kuning & Warna kuning & Warna & Warna kuning \\
& kuning & Tidak ada & Tidak ada & kuning & Tidak ada \\
& Tidak ada & endapan & endapan & Tidak ada & endapan \\
& endapan & & & endapan & \\
& Jernih & Jernih & Jernih & Agak keruh & Agak keruh \\
& Warna & Warna kuning & Warna kuning & Warna & Warna kuning \\
A2 & kuning & Tidak ada & Tidak ada & kuning & Tidak ada \\
& Tidak ada & endapan & endapan & Tidak ada & endapan \\
& endapan & & & endapan & \\
& Jernih & Jernih & Sedikit ada & Agak keruh & Agak keruh \\
& Warna & Warna kuning & minyak yang & Sedikit ada & Sedikit ada \\
& kuning & Tidak ada & terpisah, warna & minyak yang & minyak yang \\
& Tidak ada & endapan & kuning & terpisah, & terpisah, \\
& endapan & & & warna kuning & warna kuning \\
\hline
\end{tabular}



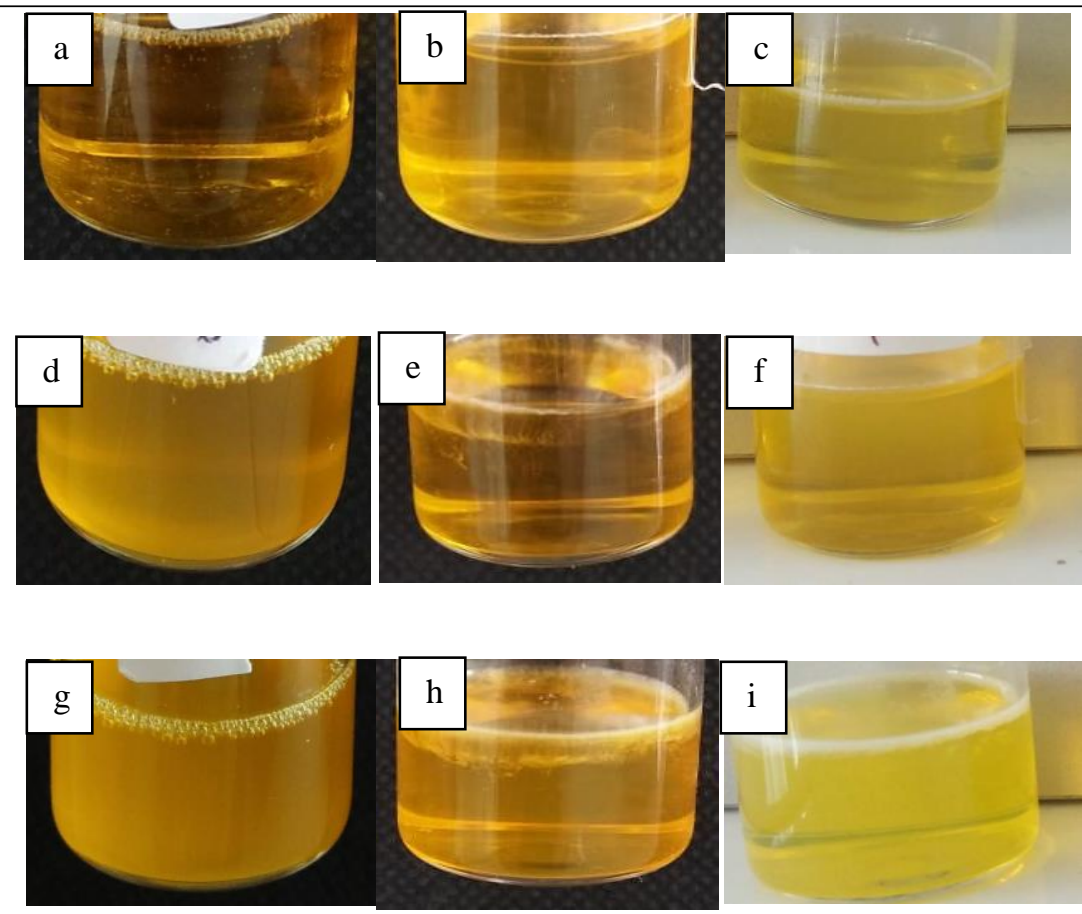

Gambar 1. Hasil Organoleptik Mikroemulsi selama 28 Hari. Formula A1 pada Hari Pertama (a), Hari ke-14 (b) dan Hari ke-28 (c). Formula A2 pada Hari Pertama (d), Hari ke-14 (e) dan Hari ke-28 (f). Formula A3 pada Hari Pertama (g), Hari ke-14 (h) dan Hari ke-28 (i).

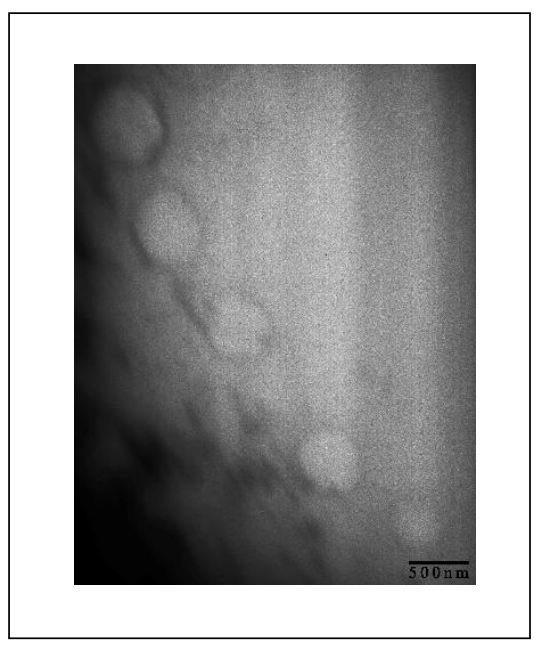

Gambar 2. Morfologi Mikroemulsi A1 (Perbesaran 15.000x)

\section{Bobot Jenis}

Hasil pengukuran bobot jenis mikroemulsi dapat dilihat pada Tabel 1. Dari hasil pengukuran terlihat bahwa bobot jenis formula $A 1, A 2$, dan A3 tidak jauh berbeda dengan air sehingga dapat disimpulkan bahwa mikroemulsi yang terbentuk adalah jenis mikroemulsi minyak dalam air karena banyaknya komposisi air. Mikroemulsi dengan komposisi air yang banyak menunjukkan bahwa rendahnya viskositas mikroemulsi. Hal ini dapat menjadi kekurangan dari sediaan karena viskositas yang rendah dapat mempercepat pembentukan creaming (Al Abood et al. 2013). Namun, viskositas yang rendah ini dapat memberikan keuntungan pada konsumen dalam menggunakan sediaan mikroemulsi sebagai antikerut. Viskositas yang rendah akan memudahkan konsumen mengaplikasikan sediaan pada 
wajah dan memungkinkan zat aktif tersebar merata di seluruh area wajah dengan usapan yang lembut.

\section{Pengukuran Globul}

Dari hasil pengukuran globul emulsi (Tabel 1), diperoleh bahwa semakin besar komposisi CPO maka semakin besar pula ukuran globul yang diperoleh. Hal tersebut terlihat dari data yang menunjukkan bahwa formula A3 memiliki globul yang paling besar di antara 3 formula lainnya. Oleh karena itu, komposisi minyak dalam formula sangat menentukan ukuran globul mikroemulsi. Namun, ukuran globul emulsi masih belum masuk ke dalam rentang optimum, yaitu sebesar 20-200 nm (Okyar, et al. 2012). Ukuran globul yang mendekati nilai optimum adalah formula A1. Pembesaran ukuran ini dapat disebabkan karena terbentuknya misel yang memiliki ukuran yang lebih besar, sekitar 5-5000 nm (Agoes, 2012). Hal tersebut dapat diatasi dengan meningkatkan kecepatan pengadukan sehingga gaya kinetik akan meningkat. Peningkatan gaya kinetik akan membantu memecah globul menjadi lebih kecil.

\section{Pengukuran Zeta Potensial}

Pengukuran zeta potensial dilakukan untuk mengukur muatan permukaan dari globul yang berfungsi untuk mempertahankan globul untuk tetap berada pada jarak optimum dan tidak menyatu (Kale dan Deore 2017; Wang, 2014). Nilai optimum zeta potensial sediaan mikroemulsi berkisar antara +30 $\mathrm{mV}$ hingga $-30 \mathrm{mV}$, dengan nilai paling optimum yaitu mendekati 0 (Wang, 2014). Dari hasil pengukuran zeta potensial yang tertera pada tabel 1, terlihat bahwa formula yang memiliki nilai zeta potensial mendekati 0 adalah formula A1. Dari ketiga formula terlihat bahwa semakin banyak komposisi CPO maka nilai zeta potensial semakin menjauhi nilai 0 . Hal ini menunjukkan bahwa semakin banyaknya komposisi minyak dalam sediaan mikroemulsi akan menurunkan stabilitas dari mikroemulsi. Hal ini disebabkan oleh semakin tinggi atau semakin rendah nilai zeta potensial, gaya tarik menarik akan meningkat dan memungkinkan terjadinya flokulasi (Wang, 2014; Silva et al. 2013).

\section{Pengukuran pH}

Pengukuran $\mathrm{pH}$ penting dilakukan pada evaluasi sediaan mikroemulsi untuk mengetahui kesesuaian $\mathrm{pH}$ sediaan dengan pH kulit. Untuk sediaan kosmetik atau yang berkontak dengan kulit, $\mathrm{pH}$ normal yang diharapkan sebesar 4,5-6,5 (Ali dan Yosipovitch, 2013). Jika terlalu asam atau terlalu basa, sediaan dapat mengiritasi kulit. Fluktuasi $\mathrm{pH}$ ketiga sediaan mikroemulsi yang disimpan pada suhu $25^{\circ} \mathrm{C}$ selama 28 hari dapat dilihat pada Gambar 3. Selama pengamatan 14 (empat belas) hari, terlihat bahwa $\mathrm{pH}$ ketiga formula masuk ke dalam rentang yang dipersyaratkan, sehingga tidak mengiritasi kulit. Pada hari ke-28, ketiga formula melewati batas persyaratan, yaitu di atas 6,5. Untuk mempertahankan $\mathrm{pH}$ sediaan tetap stabil selama penyimpanan, formula dapat ditambahkan larutan penyangga atau buffer (Adi et al. 2019). 


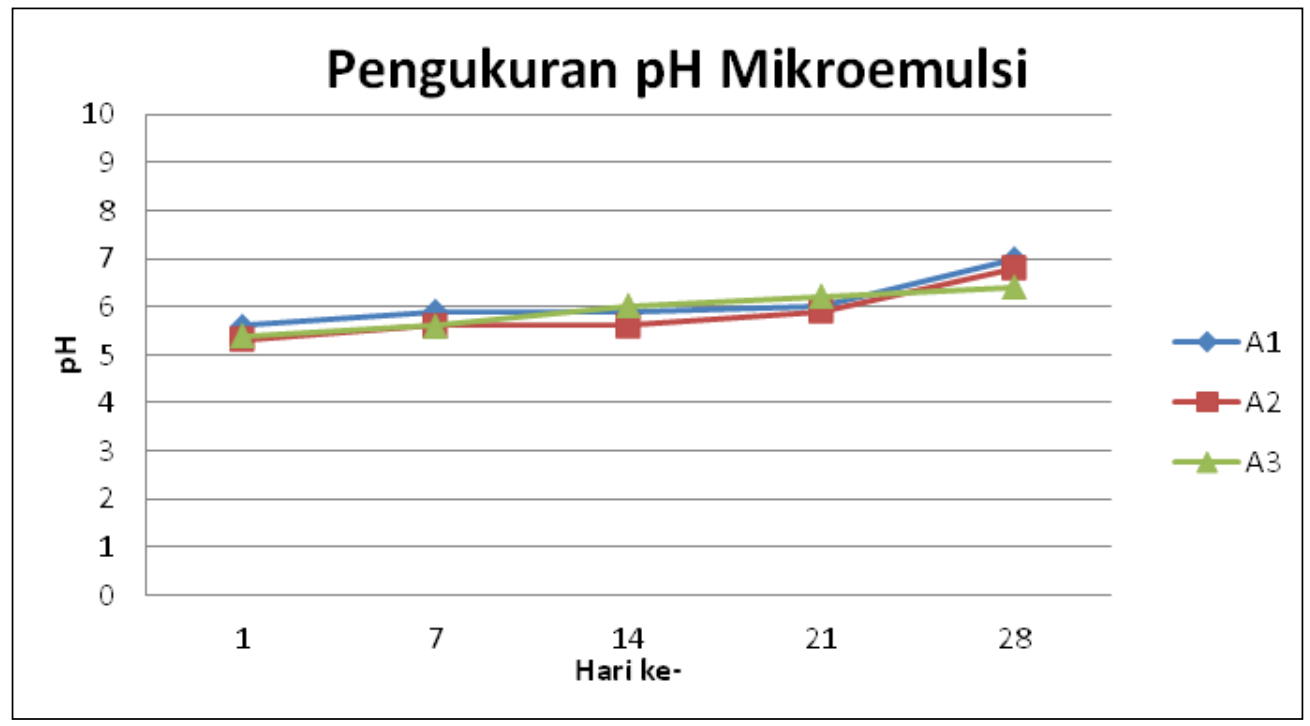

Gambar 3. Hasil Pengukuran pH Sediaan Mikroemulsi.

\section{Pengujian Stabilitas Fisik pada Suhu} $25 \circ \mathrm{C}$

Uji stabilitas terdiri dari 3 uji, yaitu uji stabilitas fisik pada suhu $25^{\circ} \mathrm{C}$, uji sentrifugasi, dan uji Freeze Thaw. Uji stabilitas fisik pada suhu $25^{\circ} \mathrm{C}$ diperlukan untuk mengetahui kestabilan mikroemulsi apabila disimpan pada suhu ruang selama 28 hari (Cinar, 2017). Hasil pengujian stabilitas fisik sediaan mikroemulsi terlihat pada Tabel 3.

Tabel 3. Hasil Uji Stabilitas Fisik Sediaan Mikroemulsi pada Suhu $25^{\circ} \mathrm{C}$

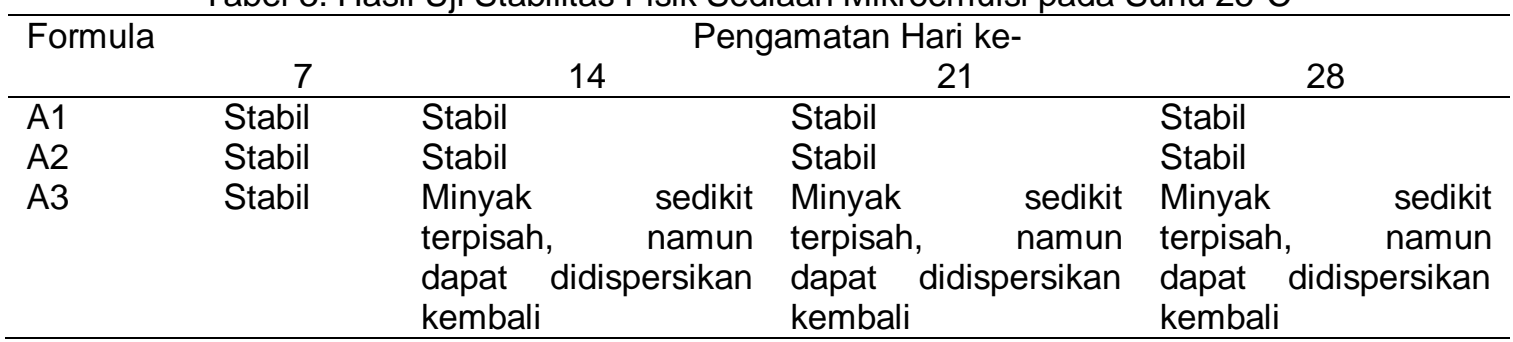

Dari hasil pengamatan (Tabel 3), tidak ditemukan adanya ketidakstabilan berupa creaming ataupun pemisahan fasa pada formula A1 dan A2. Namun pada formula A3 pada minggu ke-14, ditemukan adanya sedikit keterpisahan fasa, namun masih dapat didispersikan kembali dengan pengocokan ringan. Hal ini dapat diakibatkan karena kurang tepatnya komposisi antara minyak, air, dan surfaktan dalam formula tersebut.

\section{Pengujian Sentrifugasi}

Uji sentrifugasi bertujuan untuk melihat ketahanan mikroemulsi terhadap agitasi atau getaran. Dari hasil uji sentrifugasi yang terlihat pada Gambar 4, ketiga formula tersebut tetap stabil setelah agitasi, ditandai dengan tidak adanya creaming ataupun pemisahan fasa pada sediaan. 


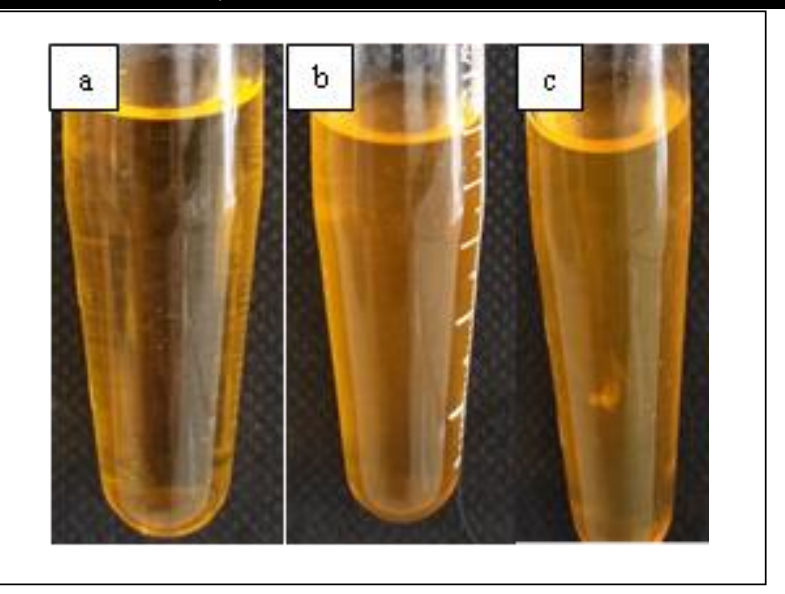

Gambar 4. Hasil Uji Sentrifugasi Sediaan Mikroemulsi (a) A1, (b) A2, (c) A3.

\section{Pengujian Siklus Freeze Thaw}

Uji Freeze Thaw dilakukan selama 3 (tiga) siklus untuk melihat kestabilan mikroemulsi terhadap perubahan suhu ekstrim. Hasil yang diamati adalah perubahan ukuran globul yang dihasilkan setelah siklus berakhir. Hasil dari siklus Freeze Thaw dapat dilihat pada Tabel 4.

Dari tabel 4 terlihat bahwa ukuran globul formula $A 1$ relatif stabil, namun terjadi pembesaran globul signifikan pada A2 dan A3. Hal ini menunjukkan bahwa semakin banyak komposisi minyak pada sediaan mikroemulsi (Tabel 1), globul yang terbentuk semakin besar. Ukuran globul yang besar ini dapat meningkatkan kemungkinan adanya flokulasi atau penggabungan dua globul. Penggabungan dua globul atau lebih ini dapat menurunkan stabilitas dari mikroemulsi. Oleh karena itu, penambahan komposisi minyak yang terlalu banyak tidak disarankan karena dapat mempengaruhi stabilitas dari sediaan mikroemulsi.

Tabel 4. Hasil Evaluasi Siklus Freeze Thaw Sediaan Mikroemulsi

\begin{tabular}{lc}
\hline Formula & Ukuran Globul setelah Freeze thaw 3 siklus $(\mathrm{nm})$ \\
\hline A1 & 287,6 \\
A2 & 673 \\
A3 & 1080 \\
\hline
\end{tabular}

\section{Pengujian Antioksidan}

Pada penelitian ini digunakan IC50 sebagai parameter untuk pengukuran kekuatan antioksidan dari sediaan mikroemulsi CPO. Nilai IC50 adalah besaran konsentrasi yang dibutuhkan untuk menghambat $50 \%$ aktivitas radikal bebas. Semakin kecil nilai IC50, semakin baik aktivitasnya sebagai antioksidan.

Pengujian aktivitas antioksidan ini diujikan pada formula yang menunjukkan karakterisasi fisik terbaik, yaitu formula mikroemulsi A1. Pada penentuan nilai IC50 sediaan mikroemulsi A1, diperoleh nilai IC50 sebesar 10,5 $\mu \mathrm{g} / \mathrm{mL}$. Nilai tersebut digolongkan sebagai aktivitas yang sangat kuat, karena semakin rendah
IC50, semakin tinggi aktivitas antioksidan yang dihasilkan (Shekhar dan Anju, 2014). Selain itu, aktivitas antioksidan tersebut digolongkan memiliki aktivitas yang sangat kuat karena memiliki nilai IC50 < $50 \mu \mathrm{g} / \mathrm{mL}$ (Blois, 1958). Oleh karena itu, dapat disimpulkan bahwa sediaan mikroemulsi CPO ini berpotensi besar untuk dijadikan sediaan obat untuk mencegah penuaan dini pada kulit yang disebabkan oleh radikal bebas.

\section{SIMPULAN}

Berdasarkan evaluasi organoleptik, ukuran globul, dan pengujian stabilitas, diperoleh bahwa formula optimum dari penelitian ini adalah formula A2 yang mengandung $5 \%(\mathrm{~b} / \mathrm{b})$ 
CPO, 20\% (b/b) tween 80, 10\% (b/b) PEG 400 , dan $65 \%$ (b/b) air. Hasil evaluasi formula menunjukkan bahwa formula ini memiliki ukuran globul sebesar 288,87 \pm $20,94 \mathrm{~nm}$, zeta potensial sebesar $-0,36$ $\mathrm{mV}$, bobot jenis $1,024 \pm 6,15 \times 10^{-5} \mathrm{~g} / \mathrm{mL}$, dan $\mathrm{pH}$ berada pada rentang 4,5-6,5. Dari evaluasi stabilitas diperoleh bahwa sediaan stabil dalam penyimpanan selama 28 hari di suhu ruang $\left(25^{\circ} \mathrm{C}\right)$, stabil terhadap perubahan suhu ekstrim dan agitasi. Sediaan mikroemulsi CPO ini memiliki nilai IC50 sebesar $10,5 \mu \mathrm{g} / \mathrm{mL}$ dan menunjukkan aktivitas antioksidan yang kuat. Dari hasil evaluasi fisik dan uji aktivitas antioksidan dapat disimpulkan bahwa sediaan mikroemulsi CPO memiliki karakterisasi fisik dan kestabilan yang baik sehingga dapat dikembangkan lebih lanjut sebagai sediaan antioksidan pada kulit.

\section{Ucapan Terima Kasih}

Ucapan terima kasih penulis sampaikan kepada Lembaga Penelitian, Pengabdian kepada Masyarakat, dan Penjaminan Mutu Pendidikan (LP3) ITERA atas dana hibah penelitian yang telah diberikan melalui program Hibah ITERA SMART 2019.

\section{DAFTAR PUSTAKA}

1. Adi, I. A., Mulyani, S., \& Harsojuwono, B. A. 2019. Pengaruh Penambahan $\mathrm{pH}$ Buffer-Ekstrak Kunyit, Ekstrak Daun Asam dan Kombinasi Ekstrak Kunyit Daun Asam (Curcuma domestica Val. Tamarindus indicia L.) Terhadap Karakteristik Krim. Jurnal Rekayasa dan Manajemen Agroindustri, 347-357.

2. Agoes, G. 2012. Mikroemulsi, In : Sediaan farmasi likuida-semisolida. Bandung: ITB.

3. Al Abood, R. M., Talegaonkar, S., Tariq, M., \& Ahmad, F. J. 2013. Microemulsion as a tool for the transdermal delivery of ondansetron for the treatment of chemotherapy induced nausea and vomiting. Colloids and Surfaces $B$ : Biointerfaces, 143-151.

4. Ali, S. M., \& Yosipovitch, G. 2013. Skin $\mathrm{pH}$ : From Basic Science to Basic Skin Care. Acta Dermato Venereologica, 261267.
5. Anonim. 2007. Gambaran Sekilas Industri Minyak Kelapa Sawit. Jakarta: Departemen Perindustrian.

6. Anonim, 2019. pertanian.go.id. Retrieved April 12, 2020, from https://www.pertanian.go.id/home/?show $=$ news\&act $=$ view\&id $=3743$

7. Asri, M., Daik, R., \& Ramli, S. 2017. Study on the effect of oil phase and cosurfactant on microemulsion systems. Malaysian Journal of Analytical Sciences, 1409-1416.

8. Blois MS, 1958. Antioxidant determination by the use of stable radicals, Nature, 181: 1199-2000.

9. Cinar, K. 2017. A Review on Nanoemulsions: Preparation Methods and Stability. Trakya University Journal of Engineering Sciences, 73-83.

10. Dijaz, S. M. 2013. Preparation and study of vitamin A palmitate microemulsion drug delivery system and investigation of co-surfactant effect. Journal of Nanostructure in Chemistry.

11. Fitriani, E.W., Imelda E., Kornelis C., Avanti C. 2016. Karakterisasi dan Stabilitas Fisik Mikroemulsi Tipe A/M dengan Berbagai Fase Minyak. Pharm Sci Res. 3(1): 2407-2354.

12. Flanagan, J., \& Singh, H. 2006. Microemulsions: A Potential Delivery System for Bioactives in Food. Critical Reviews in Food Sciences and Nutrition, 221-237.

13. Hasrawati, A., Hasyim, N., \& Irsyad, N. A. 2016. Pengembangan Formulasi Mikroemulsi Minyak Sereh (Cymbopogon nardus) Menggunakan Emulgator Surfaktan Nonionik. Jurnal Fitofarmaka Indonesia, 151-154.

14. Jha, S. K., Karki, R., Venkatesh, D. P., \& Geethalakshami, A. 2011. Formulation Development \& Characterization of Microemulsion Drug delivery systems Containing Antiulcer drug. International Journal of Drug Development and Research, 336-343.

15. Kale, S. N., \& Deore, S. L. 2017. Emulsion Micro Emulsion and Nano Emulsion: A Review. Systematic Reviews in Pharmacy, 39-47.

16. Narang, A. S., Delmarre, D., \& Gao, D. 2007. Stable Drug Encapsulation in Micelles and Microemulsion. International Journal of Pharmaceutics, 9-25.

17. Nasution, Z. A., \& Limbong, H. P. 2019. Karakterisasi Arang Cangkang Kelapa Sawit Sebagai Bahan Pembantu Untuk Meningkatkan Kesuburan Tanah 
Berdasarkan Kromatografi GC-MS. Jurnal Industri Hasil Perkebunan, 62-68.

18. Ng, S. H., Woi, P. m., Basri, M., \& Ismail, Z. 201. Characterization of structural stability of palm oil esters-based nanocosmeceuticals loaded with tocotrienol. Journal of Nanobiotechnology, 11(27).

19. Okyar, A., Ozsoy, Y., \& Gungor, S. 2012. Rheumatoid arthritis treatment : novel formulation approaches for dermal and transdermal delivery of non-steroidal antiinflammatory drugs. Istanbul: InTech.

20. Pamudji, J. S., Darijanto, S. T., \& Rosa, S. 2012. Formulasi dan Evaluasi Mikroemulsi Minyak dalam. Acta Pharmaceutica Indonesia, 146-152.

21. Patel, V., Kukadiya, H., Mashru, R., Surti, N., \& Mandal, S. 2010. Development of Microemulsion for Solubility Enhancement of Clopidogrel. Iranian Journal of Pharmaceutical Research, 327-334.

22. Ramli, S., Chyi, K. T., Zainuddin, N., Mokhtar, W. N., \& Abdul Rahman, I. 2019. The Influence of Surfactant/CoSurfactant Hydrophilic-Lipophilic Balance on the Formation of Limonene-Based Microemulsion as Vitamin C Carrier. Sains Malaysiana, 1035-1042.

23. Shekhar, T. C., \& Anju, G. 2014. Antioxidant Activity by DPPH Radical Scavenging Method of Ageratum conyzoides Linn. Leaves. American Journal of Ethnomedicine, 244-249.
24. Silva, A. E., Barratt, G., Cheron , M., \& Egito, E. S. 2013. "Development of oil-inwater microemulsions for the oral delivery of amphotericin B. International Journal of Pharmaceutics, 641-648.

25. Subramanian. 2005. Formulation and Physicochemical. Characterization of Microemulsion System Using Isopropyl Miristate, Medium Chain Glyceride, Polysorbate 80 and Wate. Chemical and Pharmaceutical Bulletin, 1530-1535.

26. Syafitri, E., Adliani, N., Khoirunnisa, S. M., \& Frima, F. K. 2019. The Formulation and Physical Evaluation of CPO BasedMicroemulsion. International Conference on Science, Infrastructure Technology and Regional Development (ICoSITeR) 2019. Lampung Selatan: Institut Teknologi Sumatera.

27. Talegaonkar, S., Azeem, A., \& Ahmad, F. J. 2008. Microemulsions: A Novel Approach to Enhanced Drug Delivery. Recent Patents on Drug Delivery \& Formulation, 238-257.

28. Wang, Y. 2014. Preparation of Nano- and Microemulsions using Phase Inversion and Emulsion Titration Methods. Auckland: Massey University.

29. Yuliasari, S., Fardiaz, D., Andarwulan, N., \& Yuliani, S. 2014. Karakterisasi Nanoemulsi Minyak Sawit Merah yang Diperkaya Beta Karoten. Jurnal Littri, 20(3). 